\title{
International workshop on geodynamic evolution, tectonics and magmatism of the Central Asian orogenic belt and pre-workshop field excursion to Gorny Altay, Russia
}

\author{
June 20-30, 2010, Novosibirsk, Russia (http://altay2010.igm.nsc.ru)
}

This workshop and pre-workshop field trip were organized by the Institute of Geology and Mineralogy, Siberian Branch, Russian Academy of Sciences (SB RAS) and co-sponsored by the Presidium of the Siberian Branch of the Russian Academy of Science (SB RAS), Centre for Russian and Central EurAsian Mineral Studies (CERCAMS), and Task Force 1 (ERAS) of the International Lithosphere Program (ILP). This was preceded by a field excursion to Gorny Altay in Southwestern Siberia (June 20-28, 2010), which, in the literature, is also referred to as Mountainous Altay or Russian Altay. The field excursion and the workshop attracted eighteen participants from 8 countries, namely Germany, England, Japan, China, France, Czech Republic, Poland and Russia.

The main goal of this workshop was to discuss the general evolution of the Central Asian Orogenic Belt (CAOB) with a special emphasis to the problems of continental growth, evolution of palaeo-oceans and active continental margins, collisional tectonics and metallogeny based on results of previous field missions and analytical research. This would contribute to our understanding of the
Late Neoproterozoic to Palaeozoic evolution of the Altay belt and to establish up-to-date models of ocean closure, continental accretion/assembly and intracontinental orogeny.

An important experience in joint study of the CAOB was IGCP Project 283 "Geodynamic evolution of the Paleo-Asian Ocean" and its related 1993 international field excursion to Gorny Altay. The project started with the meeting in Urumqi, 1989, which was organized by the Chinese Academy of Sciences. Project symposia took place in Ulan-Ude (1991, Russia), Shenyang (1992, China), and Kyoto (1992, Japan). The participants were scientists from China, Japan, Kazakhstan, Kyrgyzstan, Mongolia, Russia, Turkey, USA and UK. The project resulted in creation of a geodynamic map of the CAOB including Tien Shan, East Kazakhstan, southern Siberia, Mongolia, northern China. Tat for the first experience of making such a map, covering a huge territory and considering systematically selected geological and geodynamic units of the folded frame of the Siberian craton. The leaders and coordinators of the project were
L. Zonenshain, R. Coleman, T. Watanabe, X. Xuchang, E. Chang, O. Tomurtogoo, N. Dobretsov and N. Berzin.

The Altay 2010 field excursion included en-route and camp-based field observations of the major geological structure of the Gorny Altay - Middle Palaeozoic suture-shear zone, which separates the Siberian and KazakhstanBaikal continents (Fig.1). The participants had an opportunity to study - (1) the CharyshTerekta-Ulagan-Sayan suture-shear zone comprising fragments of the Late CambrianEarly Ordovician ophiolites (oceanic crust) of the Ob'-Zaysan oceanic basin and Ordovician-Silurian blueschists, turbidites and crystalline schists; (2) the units of the Late Neoproterozoic-Cambrian island-arc, accretionary and active margin, OrdovicianSilurian passive margin and Devonian active margin of the Siberian continent; (3) the Gondwana-derived Altay-Mongolian terrane - a part of the composite KazakhstanBaikal continent; and (4) the Late Palaeozoic syn- and post-collisional magmatic and metamorphic rocks, strike-slip and thrust fault structures.

During the international workshop and
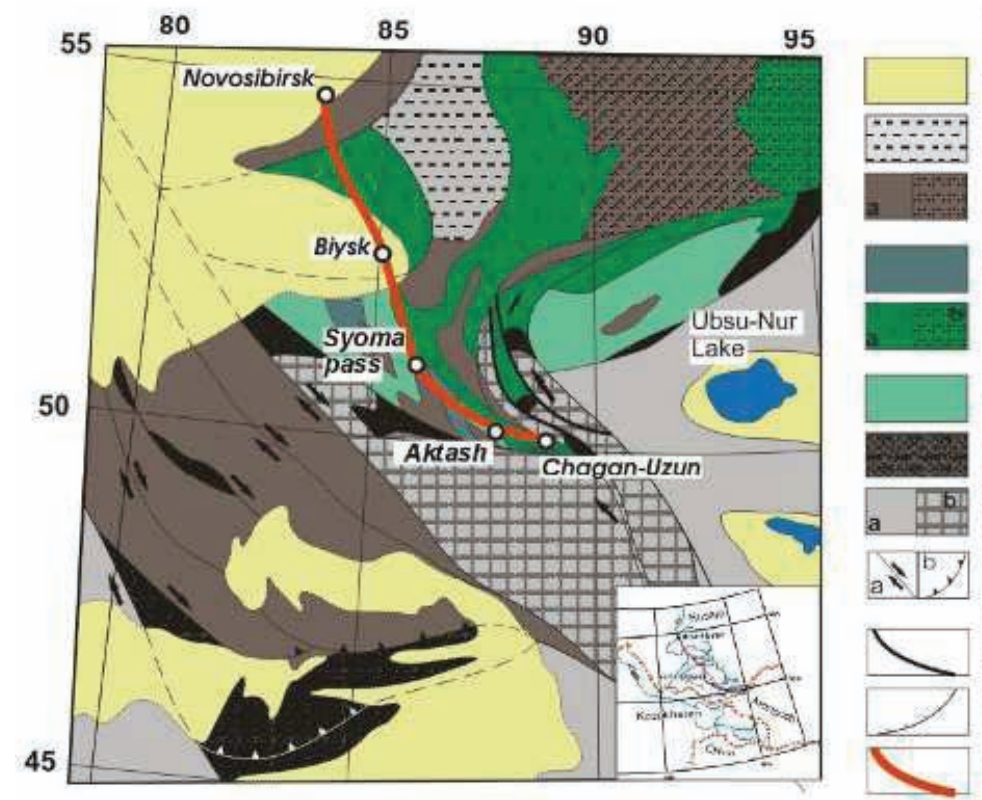

Cenozoic basins

Permian-Jurassic Kuzbass coal basin

Devonian active margin: $\mathrm{a}$ - island arc, b - back-arc basin

Ordovician-Silurian passive margin

Neoproterozoic-Cambrian active margin: a - island arc, b - back-arc basin

Cambrian fore-arc basin

Middle Paleozoic suture-shear zone

Kazakhstan-Baikal composite continent: a- undivided, b - Altay-Mongolian terrane Late Carboniferous-Early Permian faults: a - strike-slip, b - thrust

Devonian-Early Carboniferous strike-slip faults

Mesozoic thrusts

Excursion route

Figure 1. Main geodynamic units of Altay and adjacent regions and route for pre-workshop field excursion to Gorny (Russian) Altay. 

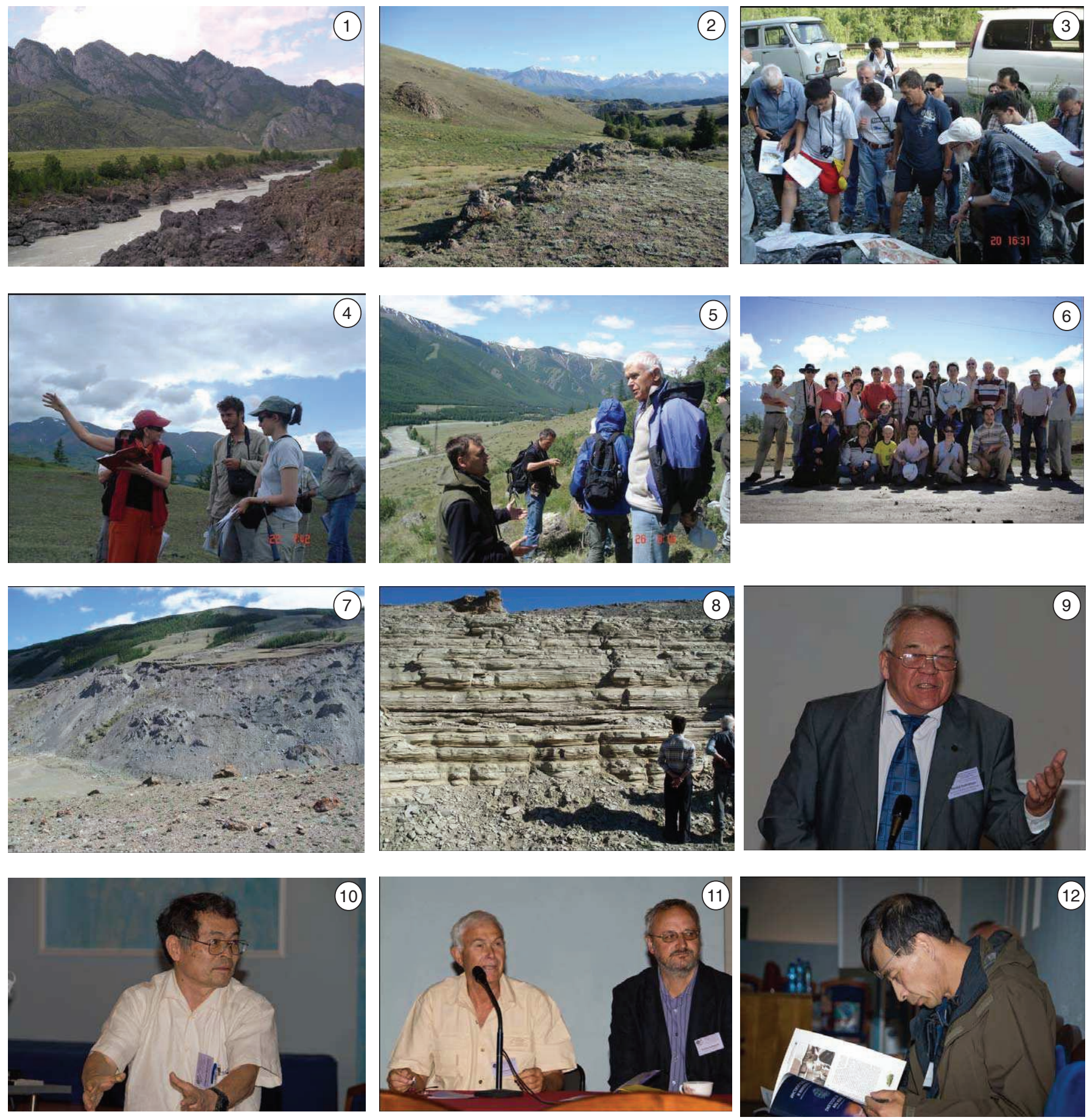

Photos from field trip and workshop. 1 - The Katun accretionary complex: paleoseamount pillow lavas and carbonate cap. 2 - View to the North Chuya Range with outcrops of the Kurai accretionary complex in the foregrounds. 3 - Studying the first outcrop - Devonian active margin (left to right, $1^{\text {st }}$ row): Alfred Kröner (Mainz), Keda Cai (Hong Kong), Vladimir Prelov (Moscow), Mikhail Buslov (Novosibirsk), Georgiy Biske (St. Petersburg). 4 - The Kurai accretionary complex: discussing origin of greenstones and other units of OPS (left to right): Inna Safonova (Novosibirsk), Jeremie Lehmann and Alexandra Guy (Strasburg), Reimar Seltmann (London). 5 - The Chagan-Uzun ophiolite massive (left to right): Dmitry Gladkochub (Irkutsk), Andrei Prokopiev (Yakutsk) and Alfred Kröner (Mainz). 6 - Friendly sunny morning in Altay. 7 - A catastrophic landslide from the 7.3 M Altai 2003 earthquake. 8 - Warves of several metres thick Cenozoic glacial sediments. 9 - Nikolai Dobretsov (Novosibirsk): mantle plumes are everywhere, why you do not want to see them! 10 - Discussing problems of tectonic erosion: Shigenori Maruyama (Tokyo). 11 - Opening ceremony of the conference: Alfred Kröner (Mainz; left) and Reimar Seltmann (London). 12 - Min Sun (Hongkong): studying the booklet of the IGM SB RAS and thinking over prospects for future cooperation. 
pre-workshop excursion the participants discussed the problems of tectonics and geodynamics of Russian Altay and adjacent territories of East Kazakhstan, North China and West Mongolia. This is of special interest because recently obtained data on these territories would allow us to re-consider the available tectonic models for the formation of the Altay orogen belt in particular and the $\mathrm{CAOB}$ in general. The results of future discussions may serve as a basis for future international research projects on global geodynamics, prospecting mineral resources and tectonic reconstructions.

The participants made 29 oral and 9 poster presentations during the workshop in four scientific sessions: (1) Geodynamic evolution of the Central Asian Orogenic Belt and problems of continental growth: role of mantle plumes, Gondwana blocks and subduction-accretion belts (conveners: $N$. Dobretsov, W. Xiao); (2) Evolution of palaeooceans and active continental margins: sedimentary, oceanic, accretionary and islandarc complexes (conveners: S. Kojima, I. Safonova); (3) Collisional tectonics and geodynamics: orogenic and post-orogenic magmatism, suture-shear zones, strike-slip faulting (conveners: A. Kröner, M. Buslov); (4) Geodynamics and metallogeny (convener: R. Seltmann). The concluding discussions were very engaged and touched such vital problems as too much speculation in the interpretation of analytical data, the necessity of field evidence for many currently available models, quality of data, time and extent of mantle plumes and their geological, geophysical and geochemical evidences, etc. An important recommendation was to launch a new IGCP project with the tentative title "Continental construction of the CAOB compared to actualistic examples from the SW Pacific (Japan to Indonesia)". Letters of support with expressions of interest to contribute can be sent to Dr. Inna Safonova (E-mail: inna03-64@mail.ru).

\section{Inna Safonova}

Mikhail Buslov

\section{International Symposium on Precambrian Accretionary Orogens and Field Workshop in the Dharwar craton, Southern India}

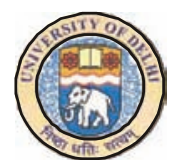

University of Delhi

\section{2-11 February 2011}

Organised by

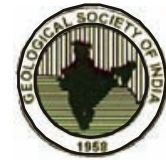

Geological Society of India

\section{Themes of the symposium}

1. Origin of continents: Early Earth Evolution (4.0 to 2.5 Ga)

2. Precambrian greenstone belts: Insights into mantle dynamics and lithosphere evolution

3. Archaean TTG and potassic granites: Insights into juvenile magmatism, continental growth and reworking

4. Precambrian sedimentary basins and evolution of early life

5. Structural patterns and tectonics of Precambrian accretionary orogens

6. Mafic dyke swarms, supercontinents and lithosphere evolution

7. Precambrian mineralisation

\section{Deadlines}

Preliminary registration $-30^{\text {th }}$ June 2010

Second circular with field workshop program $-30^{\text {th }}$ August 2010 Registration - $31^{\text {st }}$ December 2010

Submission of extended abstract $-30^{\text {th }}$ November 2010

Final circular with program $-31^{\text {st }}$ December 2010

\section{Registration fee}

Registration fee (only for 2 days symposium) - 300 euros Registration (symposium and field workshop) - 1000 euros

For further details contact:

Prof. M. Jayananda, Convener

Department of Geology, Centre of Advanced Studies

University of Delhi Delhi - 110 007, India

Tel: +91-9560714425; Fax: +91-11-27666295

Email: dharwarsymposium@gmail.com;

mjayan.geol@gmail.com; mjayangeo@rediffmail.com 